\title{
波および沿岸流共存場における水平混合倸数および 波向の推定法について
}

\author{
椹木亭*. 出口一郎**. 金 京 鍄***. 松浦 秀和****
}

\section{1. まえがき}

砕波帯内で生ずる海浜流, 平均水位変動等の現象に対 する解析は, 近年 radiation 応力の概念の導入および電 子計算機の発達に伴なって急速に進歩し, 複雑な海浜地 形に和ける入射波の砕波変形, 海浜流等の数值計算も行 われるようになってきている，一方，流速等の計測技術 も向上し, 砕波帯内の複雑な流れの場の構造が明らかに されるにつれて，先に述べた解析方法の間題点も種々指 摘されるようになってきた。 それらの問題点は，i）砕波 によるエネルギー逸散量の表現方法, ii) radiation 応力 に対して微小振幅波理論を用いることの問題点, iii) 底 部せん断力の表現法, iv) 水平混合項の表現法, v) 波向 の決定法, vi）海浜流を断面平均流として取り扱らこと の問題点等である. このらち, i) iii) の問題点に対し ては, すでに砕波帯内の流速場の詳細な測定結果に基づ いて, 有效な解決方法も示唆されている. しかし, 砕波 帯内の Reynolds 応力を表わすiv) については, 種々の モデルが提案されてはいるが，砕波帯内の乱れが普遍的 に定義され得ないことから，その妥当性に対する定量的 な検証は行なわれていない。さらに，v)の波向の決定法 についても, 従来の海浜流数值計算に㧤いては, 波数の 非回転性を利用し，微小振幅波理論に基づく分散関係式 と波と流れの干渉を考慮した波数保存則に基づて計算 されてはいるが，その妥当性についてはまだ十分検証さ れていない.

本研究は, 碎波に伴なって生ずるエネルギー逸散率に 基づく水平混合係数を提案し, 固定床平面実験に扔いて 汀線に一様な沿岸流が発生している場に怙ける, 水平方 向 2 成分電磁流速計による流速の測定及び投入された卜 レーサーの拡がりの測定結果に基づいて，提案した水平 混合係数の妥当性を検証すると同時に, 砕波带内に和け る流速場の鉛直構造, 特よび波向の決定法について考察 を加えるものである.

\footnotetext{
* 正会員 工博 大阪大学教授 工学部土木工学科

** 正会員 工博 大阪大学助教授 工学部土木工学科

*** 正会員 工鉴 忠北大学助教授 工科大学土木工学科

***** 正会員工修 風山県宁
}

\section{2. エネルギー逸散率に基づく混合係数につい $\tau$}

先に述べたように，波及び流れが共存する場の Reynolds 応力に対する水平混合項は，海浜流の空間分布を 決定する重要なパラメータであり，従来は混合係数を用 いた拡散形の表現が行われて和り，混合係数に対しては さまざまな形のものが提案されている.一方, 砕波帯内 の Reynolds 応力が，平均流の局所的な勾配に支配され るということ自体に対する問題点も指摘されている.し かしここでは, まず水平混合項に対して拡散形の表現を 用いた場合の混合係数がいかなる形で表現されるべきで あるかといらことについて，エネルギー逸散と関係づけ て考察を行い, 従来あまり議論されていなかった水平混 合係数が入射波波形勾配及び海底勾配にどの程度依存し ているかということについて検討する. 検討に当って は，以下の仮定をもらける．i）運動量の混合と物質拡散 は同様の機構で生ずると考兄られることから, 混合係数 に対しても Richardson の 4/3 乗則が準用ができるもの とする．ii）砕波による乱れ土ネルギーの発生率（波動エ ネルギー逸散率) $D$ と乱れエネルギー逸散率とは平衡状 態にある. iii) 混合のスケール $\sqrt{\bar{Y}^{2}}$ は水深のオーダ である.

これらの仮定に基づいて，仮定 i）より混合係数 $K$ は $\varepsilon$ と $\sqrt{\bar{Y}^{2}}$ を用いて次式のように表わされる.

$$
K \sim \varepsilon^{1 / 3}\left(\sqrt{\bar{Y}^{2}}\right)^{4 / 3}
$$

一方, 仮定 ii), iii）より

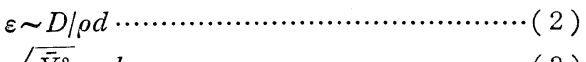

$$
\begin{aligned}
& \sqrt{\bar{Y}^{2}} \sim d
\end{aligned}
$$

と表わされる.ここに $\rho$ は水の密度, $g$ は重力加速度, $d=h+\bar{\eta}$ ( $h$ : 静水深, $\bar{\eta}$ : 平均水位変動量) である.

著者らは先に, 海底勾配 $S=1 / 8 \sim 1 / 50$, 波形勾配 $H_{0} / L_{0}=0.008 \sim 0.07$ の範囲で行われた 2 次元砕波变形 に関する実験結果に基づき，砕波帯内での波浪エネルギ 一逸散率 $D$ が (4) 式で表わされることを明らかにし。 入射波高が数 $\mathrm{cm}$ から $2 \mathrm{~m}$ に及ぶ広範なスケールの入 射波の碀波変形が（4）式を用いて説明できることを明 らかにしている1). 


$$
D=C F \rho^{-1 / 2} \cdot d^{-3 / 2} \cdot E^{3 / 2}
$$

ここに $C=0.18, E=\rho g H^{2} / 8, H$ は波高であり, $F$ は surf similarity parameter $\xi_{0}$ 及び海底勾配 $S$ を用いて 次式で表わされる.

$$
F= \begin{cases}5.3-3.30 \xi_{0}-0.07 S^{-1} & \text { 确波帯内 } \\ 0 & \text { 确波帯外 }\end{cases}
$$

式（2）（5）を式（1）に代入し, 整理すると比例定 数を $A$ として $K$ は次式のように表現できる.

$$
K=A F^{1 / 3} \sqrt{g d} \cdot H
$$

さらに, 平均水位上昇を考慮した平均汀線から沖側に $x^{\prime}$ 軸をとり, 水深波高比 $\gamma=H / d$ を用いると, 式 (6) は次のように変形される。

$$
K= \begin{cases}A F^{-1 / 3} \gamma S^{*} x^{\prime} \sqrt{g d} & \text { 研波帯内 } \\ 0 & \text { 砕波帯外 }\end{cases}
$$

ここに $S^{*}\left(=\left(0.4125 \xi_{0}+0.98\right) S\right)$ は平均水位変動を考 慮した海底勾配である.

一方, Longuet-Higgins ${ }^{2}$ は Prandtl の混合長理論に 基づき，また Battjes ${ }^{3)}$ はエネルギー逸散量と関係づけ た考察を行らことにより，とれぞれに対して式（8）お よび（9）を提案している.

$$
\begin{aligned}
& K=N_{x} \sqrt{g d} \ldots \ldots \ldots \ldots \ldots \ldots \ldots \ldots \\
& K=M\left(5 \gamma^{2} / 16\right)^{1 / 3} S^{4 / 3} x \sqrt{g d}
\end{aligned}
$$

式（7）と式（8）特よび（9）を比較して明らかな ように, 式 $(7)$ に和いては，Kは波浪及び海岸特性 を示す $H_{0} / L_{0}, \gamma$ および $S$ をすべて含んだ形で表現さ れており，したがって，無次元定数 $A$ は式（8）和よ び（9）の $N$ および $M$ に比べてょり普遍定数に近い ものと考えられる. そこで式 (7) において，Kが $H_{0} / L_{0}$ および $S$ にどの程度依存しているかということ を明らかにするために, 式 (7) 中の $F^{1 / 3} \times S^{*}$ と $H_{0} /$ $L_{0}$ の関係を示したのが図一1である.

図一1より明らかなように $F^{1 / 3} \times S^{*}$ は $H_{0} / L_{0}$ にはほ とんど依存せず，S のみの関数となる. したがって, 混 合係数には $H_{0} / L_{0}$ は直接的には関係せず，式（7）は $H_{0} / L_{0}$ の効果が含まれてはいるものの, 実際には Battjes によって提案された式（9）に近い特性をるつものと思

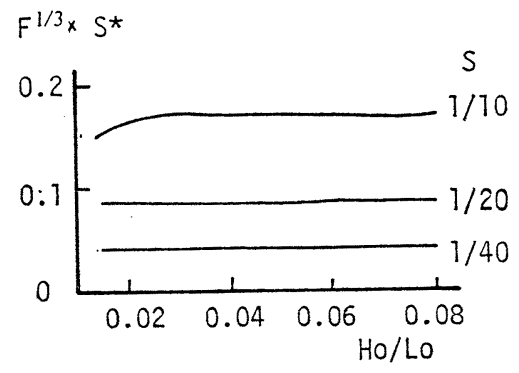

図一1 $H_{0} / L_{0}$ による $F^{1 / 3} \times S^{*}$ の変化
われるが，その妥当性については後で検討を加えること とする。

\section{3. 波向について}

通常海浜流の数值計算に和ける波向の計算は, 波数の 非回転条件と波数保存則に基ついて行われている.

一方, 波向の測定は, 水平方向 2 成分流速計による流 速の湘定結果，あるいは波峯と汀線のなす角を測定する ことによって行われて和り，実験室に拈いては主として 後者の方法で行われてきた. しかし，特に研波帯内にお いては，波峯線を明確にとらえることが困難であること から，この方法による波向の測定には大きな誤差を含む おとれがある、したがって先に述べた波向計算法の妥当 性は，計算された波向と実測された波向を直接比較する ことによってではなく, 結果として計算される海浜流が ぞの程度現象を再現しているかどうかといらことによっ てのみ判断されているのが現状である.

そこで，本研究に新いては，固定床平面実験で発生す る沿岸流速場を小型 2 成分電磁流速計によって測定し, 測定された流速および写真撮影された波峯線から求まる 波向と，先に述べた方法で計算される波向とを比較する ことにより，波向測定执よび計算方法の問題点に対する 検討も行った. このとき, 汀線方向及び岸沖方向の測定 された流速を $v$ 执よび $u$ とする, 波向の計算には次 に示す 2 通りの方法が考光られる.

$$
\begin{aligned}
& \theta_{p}=\tan ^{-1}\left\{2 \overline{\left(u-U_{0}\right)\left(v-V_{0}\right)} / \overline{\left(u-U_{0}\right)^{2}}-\overline{\left(v-V_{0}\right)^{2}}\right\} / 2 \\
& \theta(t)=\tan ^{-1}\left(V_{w} / U_{w}\right)
\end{aligned}
$$

ここに添字 0 および $w$ はとれぞれ時間平均流速と, 時 間平均值を引いた变動成分の位相平均值を示す.

\section{4. 沿岸流速測定に関する平面実験}

\section{1 実験装置と方法}

実験は, 長さ $20 \mathrm{~m}$, 幅 $10 \mathrm{~m}$, 高さ $0.6 \mathrm{~m}$ の平面水 槽内に造波板に対して $30^{\circ}$ の角度をなす平行等深線を もつ海底勾配 1/10 のモルタル製模型海浜を設置して行 った. 一様水深部の水深は $0.4 \mathrm{~m}$ である. 実験波は, 換算沖波波形勾配 $H_{0}^{\prime} / L_{0}=0.015,0.033$ および 0.052 の 3 種類で，それぞれの周期 $T$ は $0.91 \mathrm{sec}, 1.15 \mathrm{sec}$ 及び $1.44 \mathrm{sec}$ である.

波向の測定は，6台の容量式波高計を用いて模型海浜 の中央及びその両側 $2 \mathrm{~m}$ に設けた 3 本の測線上, 静水 時汀線から沖へ $10 \mathrm{~cm} \sim 130 \mathrm{~cm}$ の間を $10 \sim 20 \mathrm{~cm}$ 間隔 に測定した. 流速の測定は, 先に述べた電磁流速計によ って, 模型海浜の中央測線上の波高測定点と同一測点上 で水深方向 1 〜 点に扣いて行った. また, これらの測 定と同時に，投入した径約 $4 \mathrm{~mm}$ のウレタン製トレーサ 一及び波峯線を $16 \mathrm{~mm}$ シネカメラで撮影することによ 
り，ラグランジェ的な平均流速拉よびトレーサーの拡が りの時間変化から拡散係数の測定拉よび波向の測定も行 った．な拈，水位変動および流速の測定結果は，一測点 につき 40〜50 周期の長さにわたり $\Delta t=0.1 \mathrm{sec}$ 間隔で digital data recorder に収録し，その時間平均值政よび 位相平均值をもって表わした。

図一2 4 亿側定された位相平均波高 $H$, 平均水位変
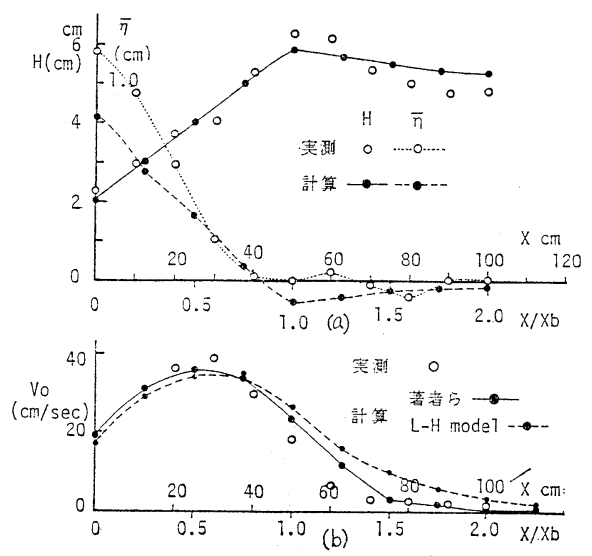

図-2 波高, 平均水位, 沿岸流速 $\left(H_{0} / L_{0}=0.015\right)$
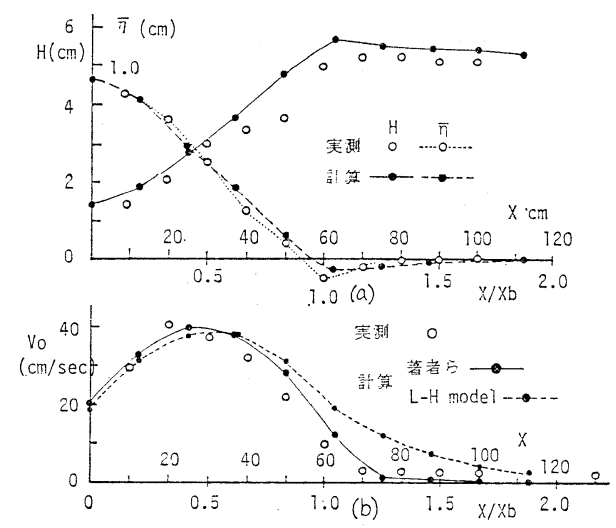

図-3 波高, 平均水位, 沿岸流速 $\left(H_{0} / L_{0}=0.033\right)$
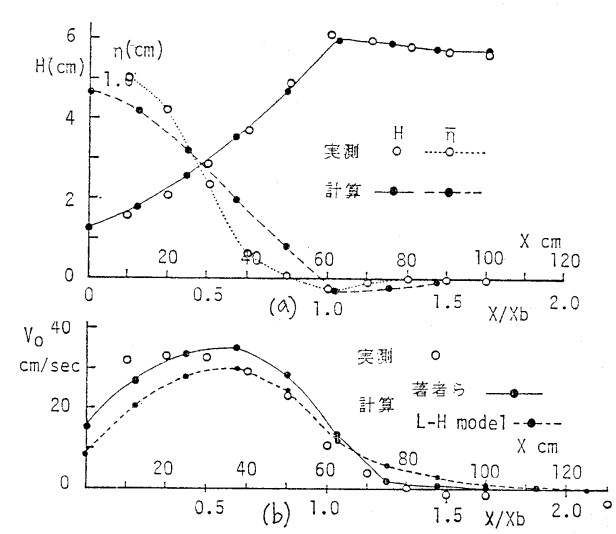

图-4 波高, 平均水位, 沿岸流速 $\left(H_{0} / L_{0}=0.052\right)$
動量 $\bar{\eta}$ および沿岸流速 $V_{0}$ の岸沖方向分布を示してお $<$.

\section{2 沿岸流速の鉛直分布および定常離岸流について} 拡散係数特よび波向に対する考察を行う前に，まず, 実験で測定された沿岸流の鉛直分布および定常な離岸方 向流れに対して簡単な考察を加えて抏こう。

図一5 (a ) (b ) 飞 $H_{0}=L_{0}=0.015$ の場合に測定さ れた沿岸及び岸沖方向流速の平均值 $V_{0}$ 及び $U_{0}$ の断面 分布を示す。図（a）より明らかなように， $V_{0}$ は少な くとも波谷より下の部分に扔いては鉛直方向にほぼ一様 な分布を示す。図一2 4 亿示す沿岸流速は，このよう な鉛直分布の平均値を示したものである.

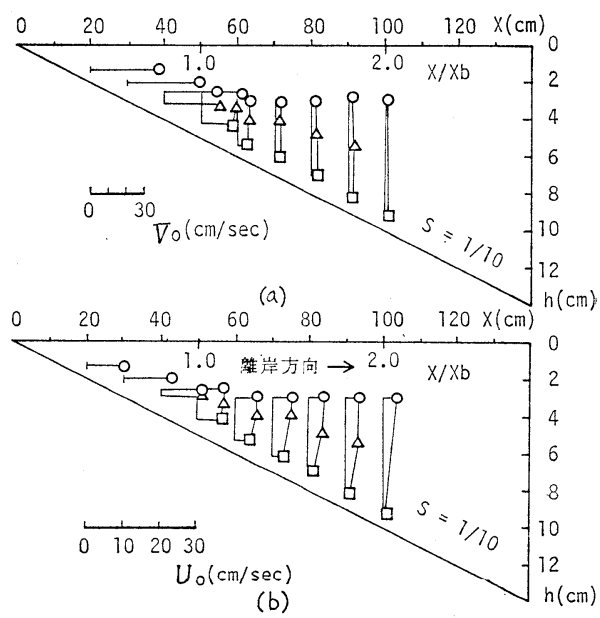

図一5 沿岸および岸沖方向平均流速の断面内分布

一方, 図の（b ）飞示す $U_{0}$ は，すべて離岸方向に向 き，底部で小さく，上層で大きくなる鉛直分布を示し， その最大值は砕波帯内で生じている．このような離岸方 向の時間平均流は，いわゆる海浜流系としての離岸流な のか，あるいは向岸方向への質量輸送に対する補償流な のかは明らかではない. Bowen は 3 次元海浜に和ける 平均流は鉛直方向には一様な分布を示す傾向の強いこと を指摘している．乙かし，2次元傾斜海浜においては， 質量輸送を補償する定常な流れが存在することが古くか ら指摘されて和り, 最近, 灘岡ら特よび Svendsen ${ }^{5)}$ に よって詳細な実験的, 理論的な研究が行われている. そ こで今回測定された離岸方向時間平均流速 $U_{0}$ が 2 次元 実験で測定される補償流とどのような対応を示すかとい らことについて検討しておく.

図一6 は，灘岡らによって2 次元傾斜海浜上で測定さ れた $U_{0}{ }^{4)}$ と，それに近い特性をるつ入射波の下で行わ れた本実験に扔いて測定された $U_{0} を \sqrt{g h_{b}}\left(h_{b}\right.$ : 确波 水深）で無次元化して比較したるのである.

図一6より明らかなように，本実験で測定された $U_{0}$ は，2 次元傾斜海浜で測定された $U_{0}$ とほぼ同様の岸沖 


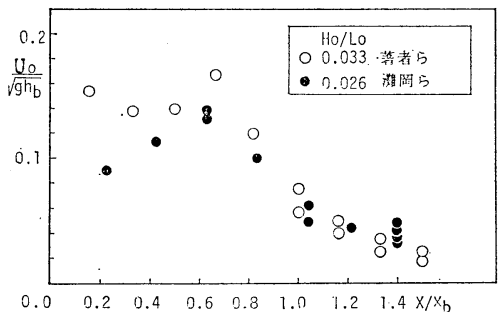

図一6 2 次元㧍よび 3 次元傾斜海浜法打る離岸方向平均 流速の比較

方向分布を示し，同程度の大きさをるつことがわかる． したがって，3次元傾斜海浜の砕波带内に和いて，汀線 方向に一様な沿岸流が発生している場に执いても，2 次 元傾斜海浜同様の補償流が存在すると考えてさしつかえ なからう．このような離岸方向の平均流は $H_{0} / L_{0}=0.052$ の場合にも測定されて特り，その最大值は波形勾配には

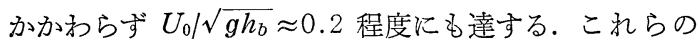
事実から，時間平均底部せ九断力あるいは漂砂移動を議 論するにあたっては，補償流の存在が決して無視し得な いものと考觉らるる。

\section{3 拡散係数について}

図一7は，今回行なった 3 ケースの実験で，沿岸流が

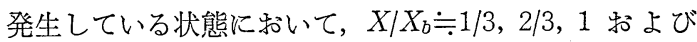
3/2 の位置に連続的に投入したトレーサーの拡がりの時 間変化率から計算した拡散俰数を示したるのである.

図一7 上り明らかなように，拡散係数は入射波波形勾 配が増加するにつれて若干増加する傾向を示し，さら 飞, 汀線からの距離の $3 / 2$ 乗に比例して增加し挽波带外 では完全に0になる，一方，2.で述べたように，混合 係数は $S, \gamma$ 及び $X^{3 / 2}$ 飞比例して増加する.

図一2〜4 より明らかなように，本実験において測定 された波高から求まる水深波高比 $\gamma(=H / h+\bar{\eta})$ は， 汀線怙よび砕波点付近を除けばほぼ 0.8 1.2 程度の值 を示すが，波形勾配による差異よりも，場所的な変動の 方が大きい，乙たがって，本実験に和ける混合俰数も， 図一7 に示す拡散係数同様, 波形勾配への依存性は明確 飞は表われないものと考光られる。ささらに，混合と拡散 が同様の機構で生ずるものと考学られることから，先に 導びいた混合係数の モデル式（7）は妥 当なものであると推 定される.

この点をさらに確 認するために，波数 の非回転性, 波数保 存則, 質量, エネル ギーフラックス及び 運動量フラックスの

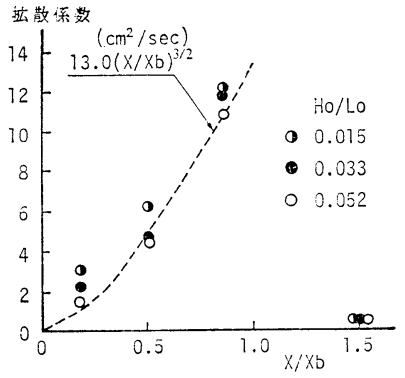

図一7 拡散係数の岸沖方向分布
保存則に基づく海浜流の数值計算法において，式（4） で示されるエネルギー逸散率拈よび式（7）で示され る水平混合係数を用いて，実験水槽内で生ずる波浪変 形及び海浜流の数値計算を行った. 計算結果は図一2 4 に特いて実測值と比較して示してある。ただし，本計 算に和いては radiation 応力については, 従来の微 小振幅波を用いた值に $0.6 \sim 0.7$ 程度のてい減俰数をか けて求めている1)。 また，式（8）で示される LonguetHiggins によって提案された水平混合係数を用いた場合 の計算值結果（この場合も上述のてい減保数を乗じてい る）る比較のために示してある.なお，これらの計算結 果はすべて，波と流れの干渉を考慮したものである。

図一2 4 から明らかなように，式（7）を用いて計 算される沿岸流速は実测値ときわめてよい一致を示し， 特に $X / X_{b}>1.0$ の砕波帯外法护る計算結果は式 (9) を用いた場合の結果に比べてより再現性の高い予測值を 与光ている。

\section{4 波向について}

最後汇波向の決定法について考察を加えておく，図一 8 は, $H_{0} / L_{0}=0.015$ のケースにおいて波崒線と汀線の なす角として読及取られる波向 $\theta_{m}$ と式 (10) から求め られる波向 $\theta_{p}$ の実測結果並びに先に述べた海浜流数值 計算に掠いて波と流れの干渉を考慮した場合と考慮しな い場合に計算される波向を計算值として比較して示した ものである。

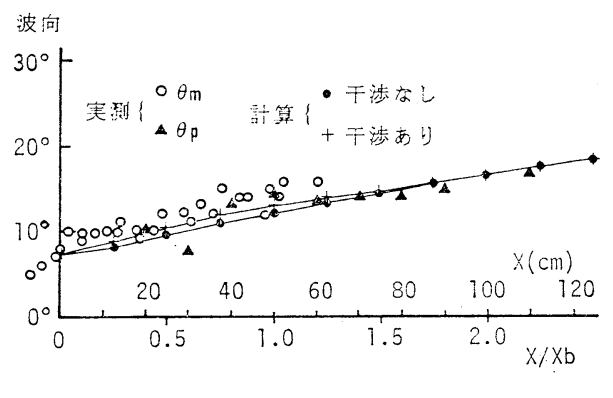

図一8 波向の比較 $\left(H_{0} / L_{0}=0.015\right)$

図一8 より，まず式（10）より求められる波の主方向 $\theta_{p}$ は $X \mid X_{b}>1$ の砕波帯外では波数の非回転性及び存保 則から計算される計算波向と良く一致していることがわ かる．また，波と流れの干渉を考慮した計算結果と考慮 しない計算結果は, 顕著な沿岸流が発生する $X / X_{3}<1$ の領域で多少の差異が生ずるが，干渉を考慮しても高々 $10 \%$ 程度波向が増大する程度にとぞまっている，X/Xb $<1$ の砕波帯内に执いて式（10）から求められる実測波 向 $\theta_{p}$ は，場所的な変動が大きいけれぞも，平均的には 波と流れの干渉を考慮して計算される波向とほぼ一致し ている.

図一9 および 10 は，図一 8 に示す $X / X_{b}=0.6$ およ 


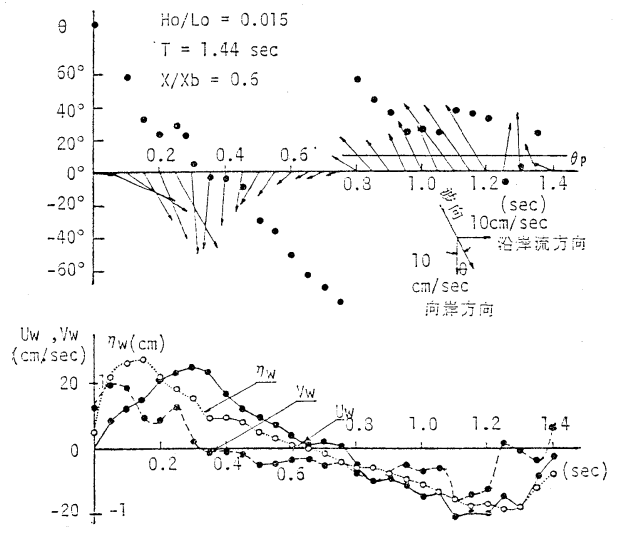

図一9＼cjkstart波による水粒子速度ベクトル（砕波带図）

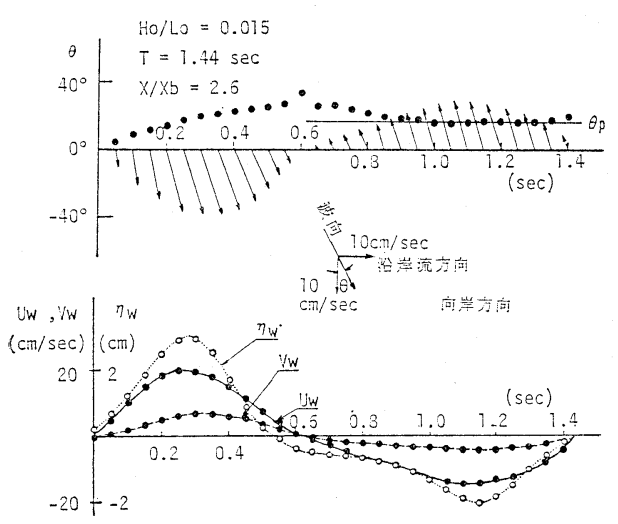

図一10 波による水粒子速度ベクトル（砕波带外）

び 2.6 に和ける位相平均水粒子速度 $U_{w}$ 特よび $V_{w}$ を ベクトル表示したもので，それぞれの図の（a）にはベ クトル $\left(U_{w}, V_{w}\right)$ 抢よび (11) から求められる実測波向 $\theta(t)$ と式 (10) から計算される実測波向 $\theta_{p}$ を，図の （b）には位相平均水位変動 $\eta_{w}$ 预よび $U_{w}, V_{w}$ の位相 変化を示してある. 図一9 に示す $X / X_{b}=0.6$ に和いて は, $\eta_{w}, U_{w}$ および $V_{w}$ の位相変化の様子が明確な対応 を示さず，特に $V_{w}$ は 30 波にわたる位相平均をとって いるにもかかわらずばらつきが大きい，乙たがって速度 ベクトルの向きから決定される波向 $\theta(t)$ も位相によって $\pm 80^{\circ}$ の範囲で大きく変動する．このときの $\theta_{p}$ に対応 する $\theta(t)$ の位相は特定することはできない.

一方, 図-10 に示す $X / X_{b}=2.6$ に特いては, $\eta w$, $U_{w}$ および $v_{w}$ 位相変化は明確に対応して和り, 特に $U_{w}$ と $V_{w}$ の位相変化の様子はよく一致している. したがっ $\tau \theta(t)$ の変動も小さく, $\theta_{p}$ を中心に $\pm 15^{\circ}$ 以内の変動 にとどまっている．また，このときの $\theta_{p}$ は $\eta_{w}<0$ と なる位相の $\theta(t)$ と完全に一致している.
以上の結果より，砕波帯外の乱れ及び沿岸流速の少な い領域に拉ける波動による水粒子運動は，ほぼ $\theta_{p}$ で決 定される方向で生じていることがわかるが，砕波に伴な って生ずる強い乱れ拉よび沿岸流が存在する場に拉ける 波動による水粒子運動は, 必ずしも $\theta_{p}$ でその運動の方 向が渗定されるわけではないことがわかる。

図一8 の砕波帯内に和いて $\theta_{p}$ が大きく変動するの は，図一9に示されるよらな水粒子速度の位相平均值の 乱れに起因しているものと考えられるが，図一9（b）に 示されているように， $U_{w}$ と $V_{w}$ の位相変化の様子が明 らかに異なることから，波による水粒子運動と平均流に よる水粒子運動が一周期内で干渉し合っている可能性も ある・

な拈，図一8 亿示す波塞と汀線のなす角度として決定 される実測波向 $\theta_{m}$ は場所的なばらつきが大きいが，そ の下限値が波と流れの干渉を考慮して計算される波向と ほぼ一致する。

\section{5.あとがき}

本論文においては，まず 3 次元傾斜海浜上で沿岸流が 発生している場に打ける水平混合係数のモデルを提案す ると同時に，平面水槽を用いた実験に和いて，小型 2 成 分電磁流速計による流速の測定を行ない，汀線および岸 沖方向の時間平均流速の特性及び波向に対する考察を加 えた. その結果, 3 次元傾斜海浜に打いても 2 次元海浜 同様の離岸方向への補償流が存在すること, 著者らの新 しく提案した水平混合係数が妥当なものであること等が 明らかになった. 一方, 波向については, 従来の非回転 性と波と流れの干渉を考慮した波数保存則から計算され る波向が，ほぼ妥当な值を与兄ているよらであるが，波 向の測定法を十分確立するにいたらず，結論づけまでに はいたっていない.

\section{参考 文 献}

1) Sawaragi, T., I. Deguchi and K. Kim: Energy loss and wave set-up in the surf zone, Tech. Rept., OSAKA Univ.,

2) Longuet-Higgins, M. S.: Longshore currents generated by obliquely incident sea waves, J.G.R., Vol. 75, No. 30, pp. 6790 6801, 1970.

3) Battjes, J. A.: Modeling of turbulence in the surf zone, Proc. Symp. Modeling Technique, pp. 1050 1061, 1975.

4) Svendsen, I. A.: Mass flux and undertoe in a surf zone, Coastal Eng., Vol. 8, pp. 347 365, 1984.

5）灘岡和夫・近藤隆道・田中則男：レーザードップラー流速 計による砕波帯内の流速場構造の解明, 港湾技研報告, 第 21 巻, 第 2 号, pp. 49 106, 1982. 